\title{
Mock-up Test for NOx Reduction by Photocatalyst Paint for Indoor Use
}

\author{
Yong Woo, Song ${ }^{1}$, Min Young, Kim ${ }^{1}$, and Jin Chul, Park ${ }^{2 . *}$ \\ ${ }^{1}$ Graduate School Students, School of Architecture and Building Science, Chung-Ang University, 06974, South Korea \\ ${ }^{2}$ Professor, School of Architecture and Building Science, Chung-Ang University, 06974, South Korea
}

\begin{abstract}
In this study, the photocatalyst $\mathrm{TiO}_{2}$ was mixed with a general paint and applied on indoor walls as part of a mock-up test to measure the reduction in the NOx concentration affected by the on or off state of a UV lamp. The findings may be summarized as follows; the NOx concentration was reduced by approximately $7 \%$ more $(0.134 \mathrm{ppm})$ with the UV lamp on than when the lamp was off in the indoor space where the paint mixed with $\mathrm{TiO}_{2}$ was applied.
\end{abstract}

\section{Introduction}

In recent years, particulate matter (PM10) have received much public attention due to their effects on health. Particularly, in Korea, the level of particulate matter is relatively higher than that in other major OECD countries. With many people currently spending more than $90 \%$ of their time indoors, particulate matter have ultimately become a health threat to indoor residents. To explore one of the methods of reducing particulate matter, a mock-up test was conducted in this study, to examine the performance of $\mathrm{TiO}_{2}$-mixed paint for indoor use in reducing NOx, one of the main precursors to particulate matter. This study will prove its usefulness, as a basic study on the reduction of particulate matter, in the future.

\section{Properties of Photocatalysts}

\subsection{Material Properties of Photocatalysts}

A photocatalyst is a material that generates a certain reaction in response to light, enabling a chemical reaction induced only by light. In general, photocatalysts are used in semiconductors. Some of the most wellknown photocatalysts include zinc oxide, cadmium oxide, tungsten oxide, and titanium oxide. The classification in accordance with the material properties of photocatalysts is shown in Table 1 below:

Table 1. Classification physical property of photocatalyst

\begin{tabular}{|c|c|}
\hline $\begin{array}{c}\text { Representative } \\
\text { properties }\end{array}$ & Contents \\
\hline $\begin{array}{c}\text { Crystallization } \\
\text { type }\end{array}$ & $\begin{array}{c}\text { Rutile, Anatase, and Brookite exist, and } \\
\text { Rutile is the most stable }\end{array}$ \\
\hline Stability & $\begin{array}{c}\text { Very stable material that does not dissolve in } \\
\text { acid, alkali, water, and organic solvents under } \\
\text { normal temperature and pressure conditions }\end{array}$ \\
\hline $\begin{array}{c}\text { Representative } \\
\text { application }\end{array}$ & Generally used in toothpaste and cosmetics \\
\hline
\end{tabular}

\footnotetext{
* Corresponding author: jincpark@cau.ac.kr
}

\subsection{Characteristics of $\mathrm{TiO}_{2}$ as Photocatalyst}

Of the four types, the photocatalyst that is used most widely is $\mathrm{TiO}_{2}$, due to its air-purifying, antibacterial, deodorizing, and other such features. Specifically, the photocatalyst may be utilized as shown in Table 2:

Table 2. Characteristics of titanium dioxide photocatalyst

\begin{tabular}{|c|c|c|}
\hline Characteristic & Contents & Representative utilization \\
\hline Antifouling & $\begin{array}{c}\text { Degradation and } \\
\text { removal of pollutants by } \\
\text { superhydrophilic action }\end{array}$ & Automotive coating \\
\hline Air Cleaning & $\begin{array}{c}\text { Removal of nitrogen } \\
\text { oxides and sulfur oxides } \\
\text { in air }\end{array}$ & $\begin{array}{c}\text { Air-purification artificial } \\
\text { plants, Building wall } \\
\text { coating }\end{array}$ \\
\hline Antibacterial & $\begin{array}{c}\text { Oxidation of organics by } \\
\text { OH radicals }\end{array}$ & Air-conditioner filter \\
\hline Deodorization & $\begin{array}{c}\text { Removal of VOCs and } \\
\text { odors }\end{array}$ & $\begin{array}{c}\text { Clothes-deodorizing } \\
\text { device }\end{array}$ \\
\hline $\begin{array}{c}\text { Water } \\
\text { Purification }\end{array}$ & Wastewater treatment & $\begin{array}{c}\text { Factory wastewater and } \\
\text { sewage treatment facility }\end{array}$ \\
\hline
\end{tabular}

Air purification of $\mathrm{TiO} 2$ photocatalysts is done through oxidation reactions, and oxidation reactions to NOx used in this experiment are shown in Table 3.

Table 3. Photocatalytic oxidation mechanism of nitrogen oxides

\begin{tabular}{|c|c|}
\hline Activation & $\mathrm{TiO}_{2}+\mathrm{hv}^{*} \rightarrow \mathrm{h}^{+}+\mathrm{e}^{-}$ \\
\hline Absorption & $\begin{array}{c}\mathrm{H}_{2} \mathrm{O}(\mathrm{g})+\text { Site }^{* *} \rightarrow \mathrm{H}_{2} \mathrm{O}_{\mathrm{ads}}, \mathrm{O}_{2}(\mathrm{~g})+\text { Site } \\
\mathrm{NO}(\mathrm{g})+\text { Site }^{* *} \rightarrow \mathrm{NO}_{\mathrm{ads}}, \mathrm{NO}_{2}(\mathrm{~g})+\text { Site } \\
\end{array}$ \\
\hline Hole trapping & $\mathrm{H}_{2} \mathrm{O}+\mathrm{h}^{+} \rightarrow \cdot \mathrm{OH}+\mathrm{H}^{+}$ \\
\hline Electron trapping & $\mathrm{O}_{2}+\mathrm{e}^{-} \rightarrow \mathrm{O}_{2^{-}}$ \\
\hline Hydroxyl attack & $\begin{array}{c}\mathrm{NO}_{\mathrm{ads}}+2 \cdot \mathrm{OH} \rightarrow \mathrm{NO}_{2 \mathrm{ads}}+\mathrm{H}_{2} \mathrm{O} \\
\mathrm{NO}_{2 \mathrm{ads}}+\cdot \mathrm{OH} \rightarrow \mathrm{HNO}_{3}\end{array}$ \\
\hline Superoxide attack & $\mathrm{NO}+\mathrm{O}_{2}^{-} \rightarrow \mathrm{NO}_{3}^{-}$ \\
\hline
\end{tabular}




\section{Mock-Up Test}

\subsection{Introduction}

For the purpose of the study, $\mathrm{TiO}_{2}-$ known for its airpurifying property - was mixed with a general paint and applied on the walls inside a mock-up test room $(2,675 \times$ $2,750 \times 2,860$ ). To confirm the air-purifying effects of $\mathrm{TiO}_{2}$, a UV lamp was used, since light energy is not as readily available in indoor spaces as in outdoor spaces. After the $\mathrm{TiO}_{2}$-mixed paint was applied on the walls, NOx, one of the major precursors to particulate matter, was injected, in the form of a gas, into the room until a certain level of concentration (2 ppm) was attained. Thereafter, the changes in the concentration were measured with the UV lamp turned on and off. The indoor temperature was set at $25{ }^{\circ} \mathrm{C}$. The details are shown in Fig. 1 and Table 3.
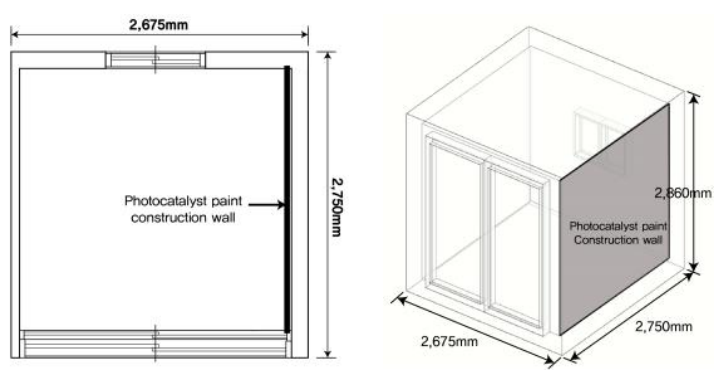

Fig. 1. Mock-Up Test Plan \& 3D Picture

Table 3. Mock-Up Test Summary

\begin{tabular}{|c|c|}
\hline Classification & Contents \\
\hline Test Gas & NO gas \\
\hline UV Lamp & UV-A BLB lamp, 0.505 mW/ $\mathrm{cm}^{2}$ \\
\hline Number of Experiments & UV ON-OFF 3 times, total 6 times \\
\hline Measurement Interval & 1 min \\
\hline Measurement Instrument & Chemiluminescence instrument \\
\hline Measurement Time & $\begin{array}{c}\text { 3 hours after attaining 2 ppm } \\
\text { concentration in test room }\end{array}$ \\
\hline
\end{tabular}

\subsection{Mock-Up Test Result}

Considering the margin of error, three tests were conducted to use the average value. Fig. 2 shows the NOx concentration rising to $2 \mathrm{ppm}$ after the precursor was introduced into the closed mock-up test room painted with $\mathrm{TiO}_{2}$-mixed paint.

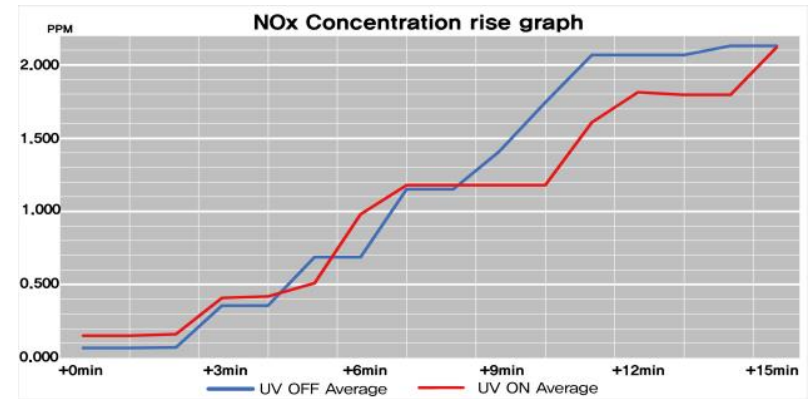

Fig. 2. NOx Concentration Rise Graph

When the NOx concentration reached $2 \mathrm{ppm}$ in the closed room painted with $\mathrm{TiO}_{2}$-mixed paint, the introduction of NOx was stopped. Fig. 3 and Table 4 show the reduction in the NOx concentration three hours after turning the UV lamp on/off. The values indicated on the graph are the averages taken from three tests, each conducted with the UV lamp on/off.

Table 4. Mock-Up Test Result

\begin{tabular}{|c|c|c|c|}
\hline Classification & UV OFF & UV ON & $\begin{array}{c}\text { Concentration } \\
\text { difference }\end{array}$ \\
\hline Start Concentration & $2.028 \mathrm{ppm}$ & $2.038 \mathrm{ppm}$ & $+0.01 \mathrm{ppm}$ \\
\hline End Concentration & $0.959 \mathrm{ppm}$ & $0.825 \mathrm{ppm}$ & $-0.134 \mathrm{ppm}$ \\
\hline
\end{tabular}

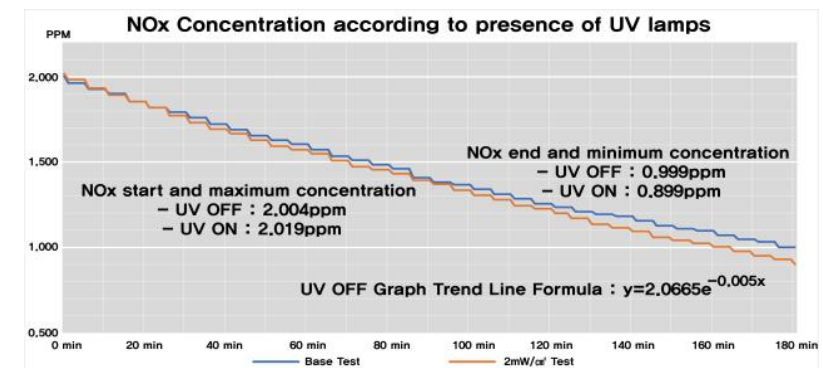

Fig. 3. NOx Concentration According to Status of UV Lamp

It was found that in the closed room where $\mathrm{TiO}_{2}$-mixed paint was applied on the walls, the NOx concentration was approximately $7 \%(0.134 \mathrm{ppm})$ lower with the UV lamp on than with the lamp off.

\section{Conclusions}

The findings of this study can be summarized as follows; In the mock-up test on an internal space where $\mathrm{TiO}_{2}$ with air-purifying property was mixed with a general paint and painted on the wall, the reduction in the NOx concentration was measured to compare the on and off states of a UV lamp. It was found that in the indoor space where $\mathrm{TiO}_{2}$-mixed paint was used, the $\mathrm{NOx}$ concentration was approximately $7 \%(0.134 \mathrm{ppm})$ lower with the UV lamp on than with the lamp off.

\section{References}

1. Y.K. Jang, Status and Problems of Fine Dust Pollution, Journal of Environmental Studies, Vol. 58, 2016. 09.

2. S.D. Kim, C.H. Kim, The Physico-chemical Character of Aerosol Particle in Seoul Metropolitan Area, The Seoul City Research, Vol. 9, 2008. 09

3. Zhang Jinhui, Li Si, Chen Lang, Pan Yi, Yang ShuangChun, The progress of $\mathrm{TiO}_{2}$ photocatalyst coating, IOSR Journal of Engineering, 2, 8, 50-53,

4. Juan Zhao, Xudong Yang, Photocatalytic oxidation for indoor air purification, Building and Environment, 38, 645-654, 2003

\section{Acknowledgements}

This research was supported by a grant (19SCIP-B146251-02) from the Infrastructure and Transportation Technology Promotion Research Program funded by the Ministry of Land, Infrastructure and Transport of the Korean government. 